Cahiers $d u$ MONDE RUSSE

\section{Cahiers du monde russe}

Russie - Empire russe - Union soviétique et États indépendants

$46 / 4 \mid 2005$

L'invention d'une politique humanitaire

\title{
zemgor and the russian army in exile
}

\section{PAUL ROBINSON}

\section{OpenEdition \\ Journals}

Édition électronique

URL : https://journals.openedition.org/monderusse/9427

DOI : $10.4000 /$ monderusse. 9427

ISSN : $1777-5388$

\section{Éditeur}

Éditions de l'EHESS

\section{Édition imprimée}

Date de publication : 1 décembre 2005

Pagination : 719-737

ISBN : 2-7132-2057-2

ISSN : $1252-6576$

\section{Référence électronique}

PAUL ROBINSON, « zemgor and the russian army in exile », Cahiers du monde russe [En ligne], 46/4 I 2005, mis en ligne le 01 janvier 2005, consulté le 04 septembre 2022. URL : http://

journals.openedition.org/monderusse/9427 ; DOI : https://doi.org/10.4000/monderusse.9427 


\section{ZEMGOR AND THE RUSSIAN ARMY IN EXILE}

The Russian Zemstvo and Towns Relief Committee, Zemgor, which was the leading Russian aid agency in the inter-war period, imagined itself to be an apolitical organisation. In its own eyes it stood above parties and party conflict, and it saw its role exclusively as a provider of humanitarian aid to Russian émigrés, based on their need not their political stance. Aid, though, is never a purely humanitarian issue. It involves decisions regarding the allocation of resources, concerning who gets them and who does not. As such, whatever the aid providers may think, their activities are inherently political. Furthermore, when people are starving, impoverished, and homeless, they are dependent on those who supply the necessities of their lives. The providers of aid can choose to channel aid to those whom they favour, and withdraw it from those who displease them. They can use it to enforce obedience to their political platforms, to compel or induce others to follow them. In short, aid and power go together.

We should not be surprised, therefore, that the provision of humanitarian aid in the early years of the Russian emigration was the cause of considerable political conflict. In particular, Zemgor clashed with the leadership of the Russian Army from the moment of its arrival in Constantinople in November 1920 onwards, as both sought to gain control of the aid effort. The exact effects of this clash on the delivery of aid are hard to determine, though they can hardly have been positive. Politically, though, the results were extremely damaging for the emigration, further dividing it and making it ever more difficult for it to present a united face to the outside world. The history of Zemgor is, therefore, as much a part of the political history of the emigration as it is of its social and cultural histories.

Zemgor and Wrangel's army were two of the most important institutions in the inter-war Russian emigration. The interaction between them directly affected the fates of tens of thousands of military émigrés, but has been largely unstudied by historians. This article provides the first in-depth analysis of the relationship between these two very different organisations during the early years of the 
emigration, and sheds light on how they and their members adapted to the circumstances of exile.

\section{The Russian Army and its Attitude to Zemgor}

In November 1920 the last significant element of the White armies which had fought against the Bolsheviks during the Russian Civil War was driven out of Russia and into exile. This was the Russian Army led by General Petr Nikolaevich Wrangel. Between March and November 1920 this army had held out against the Bolsheviks in the Crimea, but an offensive by the Red Army finally crushed its resistance, and the survivors crammed onto the ships of the Russian Navy and sailed out of Russia across the Black Sea to Constantinople. Between 13 and 16 November 1920, around 149,000 people, including 50,000 civilians, boarded 126 ships and set sail from the Crimea into exile. ${ }^{1}$ Their arrival in Turkey created a refugee crisis of huge proportions and prompted an international effort to provide humanitarian aid, which in turn prompted a review and restructuring of the provision of aid to refugees in general. In terms of the inter-war Russian emigration, this was the single largest and most important outflux of refugees, and as such it had great importance for Zemgor and the humanitarian aid effort in general.

Wrangel's Russian Army did not cease to exist when it fled Russia. Rather, once dispersed to refugees camps at Gallipoli, Chatalga, and Lemnos, the army, though reduced in size, continued to maintain itself. Not until 1927 was the command structure of the army formally dissolved, and even after that it maintained a shadowy existence in the form of the Russkii Obshche-Voinskii Soiuz (ROVS). ${ }^{2}$ The officers of the Russian Army believed that their organisation represented the last remaining institution of the Russian state (Wrangel indeed regarded himself as the head of state, and had been recognised as such de facto, if not de jure, by the French government in 1920). They described themselves as "state-minded people" (gosudarstvenno-mysliashchie liudi), and regarded the preservation of the state, and thus of the Russian Army, as of the highest importance. ${ }^{3}$ Furthermore, they believed that the only way to liberate Russia from the Bolsheviks was by armed struggle. To do this, the Russian emigration, they felt, had an obligation to maintain the army in exile so that it could be ready to resume the struggle whenever an

1. Figures for the exact number of refugees are provided in the archives of the Corps d'occupation de Constantinople, Service historique de l'armée de terre, Château de Vincennes, Paris (henceforth COC), 20 N 1156, Rapport d'ensemble sur les réfugiés russes, Exode Wrangel.

2. For the history of the army in exile and of ROVS, see Paul Robinson, The White Russian Army in Exile (Oxford: Clarendon Press, 2002).

3. See for instance, V. Kh. Davatz, Fünf Sturmjahre mit General Wrangel (Berlin: Verlag für Kulturpolitik, 1927): 12-14. 
opportunity arose. As one of the army's leading officers, General Aleksandr Kutepov put it, "budet Armiia, budet i Rossiia". ${ }^{4}$

All this meant that in the eyes of the officer corps, the preservation of the army should be the highest priority for the emigration as a whole, and consequently, such resources as the emigration had should be concentrated on supporting it. As the last remnant of Russian statehood (gosudarstvennost'), the army should also control and direct the use of the whole emigration's financial assets. According to one of the members of Wrangel's government, N. V. Savich, Wrangel wanted the money to be used exclusively for the army. ${ }^{5}$

On his arrival in Constantinople, Wrangel acted quickly to try to maintain his authority. In particular, he wished to gain control of the substantial financial resources belonging to the former Russian state which were still intact overseas. The Ambassadors of Russia in practice possessed most of these assets, so Wrangel's task was to persuade them to permit him to dispose of them, and also to persuade foreign governments of his right to take possession of the property of the Russian state in their countries. The most important country in this regard was France, and therefore in November 1920 he sent his Prime Minister Aleksandr Krivoshein, his Foreign Minister Petr Struve, and his Finance Minister Mikhail Bernatskii, to Paris to plead the army's case with the French government and to try to gain control of the available financial resources. ${ }^{6}$

Wrangel's representatives were unable to carry out the task assigned to them, due to opposition both from the Ambassadors and the French government. The former had been appointed by the Provisional Government, not by Wrangel, and had no special loyalty to him. As far as they were concerned, Wrangel no longer held state authority, and was not entitled to dispose of state assets. They were also disinclined to help him because they felt he had deceived them about the true situation in the Crimea, assuring them that all was well even when final defeat was imminent. ${ }^{7}$ When the leading Russian ambassadors, Mikhail Girs, Vassilii Maklakov, and Boris Bakhmeteff, met in Paris on 2 February 1921, they decided that as Wrangel's government no longer existed, their conference remained the only legal state authority. As such it would take on itself the responsibility for the distribution of all state property. The conference also stated that maintaining the army would be too expensive. Wrangel was mistaken to believe that the army could survive and the armed struggle be renewed. Finally, the Ambassadors determined that the distribution of aid to refugees should be concentrated in the hands of a single organisation, and that that organisation should be Zemgor. ${ }^{8}$ This was a decision of vital importance.

4. V. Kh. Davatz \& N.N. L'vov, Russkaia Armiia na chuzhbine (Belgrade: Russkoe Izdatel'stvo, 1923): 84.

5. N. V. Savich, “Konstantinopol'skii Period,” Grani, 152 (April-June 1989): 223.

6. Obshchee delo, 138 (30 November 1920): 1.

7. N. Tongour, Diplomacy in Exile: Russian Émigrés in Paris, 1918-1925 (PhD thesis, Stanford University, 1979): 313.

8. Zemgor Archive, Box "Diplomaty - Sovet Poslov," Protokol soveshchaniia poslov, Paris, 8 February 1921. 
The Ambassadors' decision was in part a result of pressure put on them by the French government, which had by now decided to abandon Wrangel. In the time it had taken the general's representatives to travel from Constantinople to Paris, his political enemies had been able to lobby the French to persuade them to drop their support for Wrangel. These efforts were successful. On 29 January 1921, the French Prime Minister Aristide Briand wrote to the head of Zemgor, Prince G. E. L'vov, that he could not accept the claims of Wrangel's representatives to administer the assets of the former Russian state. Humanitarian aid for refugees, wrote Briand, should be concentrated in the hands of Zemgor. ${ }^{9}$ This decision tied the hands of the Ambassadors. As Mikhail Bernatskii told Wrangel, Briand simply would not permit him to gain control of Russian state property, and in the circumstances it was best to let the Ambassadors take the lead in dispersing it. ${ }^{10}$ Ambassador Girs similarly told Wrangel that handing over control of aid to Zemgor was the only solution which would permit the funds available to stay in Russian hands. Otherwise, he wrote, the French would insist on taking control themselves, so leaving the Russians dependent on their goodwill. ${ }^{11}$

Whatever the true reasons for it, the Ambassadors' decision dealt a fatal blow to Wrangel's hopes of establishing himself as the leader of the Russian emigration and of maintaining his army in exile. This led to a bitter reaction in army circles. At the best of times, the officer corps was prone to a rather paranoid worldview. Its members also had a very prickly sense of honour. Many thus interpreted the downgrading of their leading role in émigré society as a personal attack, and in consequence came to see the beneficiary of the Ambassadors' decision - Zemgor - as a hostile organisation. The fact that its leaders were men of liberal political persuasion, led by the former head of the much-loathed Provision Government, Prince L'vov, was a major factor in persuading the officer corps of the army of this fact. Thus one of the army's propagandists, V. Kh. Davatz, complained that the leadership of Zemgor was an "oligarchy" of SRs and Cadets which under statute 5 of its constitution could not be changed, a fact which he considered a mockery of democratic principles. Zemgor, he complained, did all it could to make the life of the Army more difficult. ${ }^{12}$ Zemgor was led by people hostile to the army, claimed Davatz in a book co-authored with the Cadet politician N. N. L'vov. It had leftist tendencies, and was not apolitical, as it claimed. ${ }^{13}$ This image of Zemgor tarnished the army's attitudes to it henceforth.

For much of 1921, Wrangel hoped to find some way out of his predicament and to persuade émigré humanitarian organisations to accept his leadership. The prevailing attitude was expressed by Wrangel's official representative in

9. Hoover Institution Archives (HIA), P. N. Wrangel Archive (WA), Box 139, File 9, Letter, Briand to L'vov, 29 January 1921.

10. Bakhmeteff Archive (BA), Columbia University, M. Bernatskii Collection, Folder "Settlement of White Army Veterans," Letter, Bernatskii to Wrangel, 6 February 1921.

11. HIA, WA, Box 148, File 36, Letter, Girs to Wrangel, n 100, 10 February 1921.

12. Davatz, Fünf Sturmjahre mit General Wrangel: 19-20.

13. Davatz \& L'vov, Russkaia Armiia na chuzhbine: 48. 
Yugoslavia, S. N. Paleolog, who opposed giving what would nowadays be termed Non-Governmental Organisations a leading role in aid delivery. According to Paleolog, the emigration's priority should be the preservation of "state" authority (in other words the preservation of the army and of Wrangel's leadership), a priority which could not survive if authority shifted to social organisations (obshchestvennye organisatsii). ${ }^{14}$ The army, its supporters believed, should direct the work of the social organisations, not be dependent on them.

To this end, in June 1921, a medical conference of representatives of the Army and social organisations was formed in Constantinople. This coordinated their efforts and had some positive effects. In August 1921 the military medical institutions were put under the control of the Russian Red Cross. But a meeting of Wrangel and the Central United Committee (Tsentral'nyi ob"edinennyi Komitet TsOK) of the main émigré charities - the Russian Red Cross, the Vserossiiskii Zemskii Soiuz (VZS) and the Vserossiiskii Soiuz Gorodov (VSG) in August 1921 ended without agreement on how to coordinate their work. ${ }^{15}$

At this meeting, Wrangel attempted to put the activities of the social organisations under his control, and to use their means and authority to preserve the army. Wrangel proposed uniting all Russian social organisations into one institution, which would act under his direction. The leaders of the social organisations rejected this idea, even though they supported the preservation of the army. Wrangel then tried to pass responsibility for the care and provision of the troops onto them, but the members of the TsOK showed no enthusiasm for taking up the burden. ${ }^{16}$ In addition to this, the VZS defied Wrangel by refusing to let his officials audit its accounts, even though in those parts of Russia which had been controlled by the Whites, the organisation had always allowed the army to do so. The VZS now claimed, though, that Wrangel no longer possessed state authority, and instead passed it accounts to the Ambassadors for auditing. ${ }^{17}$

Despite this, the army's relations with the VZS remained good. This was not the case with its relations with Zemgor, which in part subsidised the VZS and other charities. Indeed, the army leadership, in a sense of righteous indignation, had come to convince itself that Zemgor was deliberately deceiving it. A particular bone of contention was the fate of one million francs which the army said had been handed over to Ambassador Girs by the Russian military representative in Japan, General Podtiagin. Girs in turn passed the money onto Prince L'vov on the understanding

14. HIA, S. N. Paleolog Collection, Box 2, File 8 ; Box 3, File 4, Part 1, also contains various resolutions and drafts of plans for the unification of aid delivery by the Army, Red Cross, Zemgor and other organisations.

15. S. S. Ippolitov, S. V. Karpenko, E. I. Pivovar, "Rossiiskaia emigratsiia v Konstantinopole v nachale 1920-kh godov (chislennost', material'noe polozhenie, repatriatsiia)," Otechestvennaia istoriia, 5 (September/October 1993): 81.

16. E. I. Pivovar, Rossiiskaia emigratsiia v Turtsii, iugo-vostochnoi i tsentral'noi Evrope 20-kh godov (Gottingen: Konrad Pachnicke, 1994): 28.

17. Ocherk deiatel'nosti Vserossiiskogo Zemskogo Soiuza za granitsei, aprel' 1920 g. - 1 ianvar'ia 1922 g. (Sofia, 1922): 19-20; and Zarnitsy, 19 (21 August 1921): 29. 
that it would be used to improve the living conditions of the men of the Russian Army. What happened to the money thereafter is not clear. The army High Command complained that it was not used for the specified purpose, an accusation which Zemgor denied. ${ }^{18}$ The army leadership, however, was disinclined to believe Zemgor. To it, the episode confirmed suspicions that Zemgor was using its control of émigré finances to undermine the army. For this reason, Wrangel did all that was in his power to try to prevent Zemgor gaining further influence over émigré affairs. Thus, when the League of Nations met in June 1921 to discuss the creation of a central organisation charged with dealing with the Russian refugee problem, the former Minister of War in the Provisional Government, A. I. Guchkov, went to Geneva to argue the army's case and fend off efforts by Prince L'vov and Miliukov to promote Zemgor's claim to leadership. ${ }^{19}$

Wrangel hoped that if the army could not take the leading role he desired, the Russian Red Cross could do so. ${ }^{20}$ In the end, though, the League of Nations created an entirely new organisation under the command of a High Commissioner for Refugees, Fridtjof Nansen. From the point of the view of the army, this was not a welcome outcome, since Nansen firmly believed that the best solution to the refugee problem was to repatriate Russians to Russia, a policy firmly opposed by the army leadership. The appointment of Nansen, coming on top of the Ambassadors' endorsement of Zemgor, reflected the extent to which the Russian Army had lost the battle for control of the business of aid.

\section{Zemgor and the Provision of Aid to the Army in Turkey}

The conflict between Zemgor and the Army was an inevitable product of their differing purposes and differing attitudes. The leaders of Zemgor did not share the army leadership's view of its own importance. Politically, many of them were not supporters of the army, which was seen as somewhat reactionary. They regarded the idea that the armed struggle could resume as foolish and even dangerous. This was a common view among those on the liberal left, who regarded the army not as a solution to the Russians' forced exile, but as a major part of the problem. The Russian people, some felt, would never overthrow the Bolsheviks as long as the White generals were likely to replace them. The émigrés' days of exile could only come to an end if the power of the generals was crushed, and their army destroyed.

How far the leaders of Zemgor shared such thinking, it is hard to tell, since in public they maintained the stance that their organisation was apolitical and purely humanitarian in purpose. As such, Zemgor should, they argued, direct resources to those who needed them most, rather than direct them to the army, where they would

18. HIA, WA, Box 148, File 36, Letter, Chertkov to Khripunov, n p./127, 26 April 1921. BA, ROVS Collection, Box 166, Letters, Balabanov to Guchkov, and Zeeler to Miller.

19. HIA, WA, Box 148, File 36, Letter, Guchkov to Wrangel, 30 June 1921.

20. HIA, WA, Box 148, File 36, Letter, Wrangel to S. N. Il'in, n 157/s, 12 July 1921. 
be used to keep officers employed doing very little. As able-bodied men, those officers ought to be able to care for themselves. Women, children, the disabled, and others unable to maintain themselves, should be a higher priority for the emigration's very limited funds. This very different view of what should be done paved the way to inevitable conflict. Even if Zemgor was acting for purely humanitarian purposes, its approach did constitute an attack on the army. It undermined the army's efforts to concentrate resources on its own preservation. Regardless of intention, the determination of priorities for the provision of aid was, therefore, a political as much as a humanitarian decision.

The attitude of the army to Zemgor was clear: it disliked and distrusted it. The attitude of Zemgor to the army is somewhat harder to determine. This is especially true since there is almost no correspondence between the leaders of the army and Zemgor preserved in the archives of either organisation. This reflects the fact that at the highest level their leaders were scarcely on speaking terms. On the other hand, at a lower level, relations between the army and the charitable organisations through which Zemgor operated were invariably good. Where organisations funded by Zemgor worked with members of the army, they got on well together. The conflicts were, therefore, purely at the higher levels. According to a representative of the Vserossiiskii Soiuz Gorodov in Belgrade in 1922, at a meeting with Wrangel, the latter noted "the fruitful work of the institutions of the Union of Towns in the localities, but drew attention to the politics, hostile to the army's interests, of the highest leaders of Zemsko-Gorodskii work abroad". ${ }^{21}$

Undoubtedly, Zemgor's leaders were not willing to accept any claims to leadership put forward by Wrangel. They also felt that Wrangel's efforts to preserve the army complicated the lives of his soldiers, making it harder for them to face the reality of their situation and have to adapt to a new way of life. As a report from Bulgaria noted in 1922, "dreams of preserving the former cadres [of the army] cannot be realised. The sooner the commanding staff realises this, the more painlessly and peacefully this transitional period will pass". ${ }^{2}$

Dislike of the army's leadership and its strategy did not, however, translate into a lack of concern for the ordinary soldier. Indeed, Zemgor was not at all unsympathetic to the plight of the army's soldiers, and through other organisations provided substantial aid to the army after its arrival at Constantinople.

When the Russian Army arrived in Constantinople, it was in a terrible shape. Its soldiers, along with the accompanying civilians (who included women and children) had spent several days in overcrowded vessels, with little food or water. Few had money. There was little prospect of employment in Turkey. There was a shortage of accommodation, clothing, food, and medicine. The French army, then occupying Constantinople, took the lead in providing support for the refugees. French aid included a small daily food ration, tents, and other basic supplies. These

21. Zemgor Archive, Leeds, Arkhiv n¹38, Iugoslaviia 1922-1923, Informatsiia Predstavitel'stva Vserossiiskogo Soiuza Gorodov v korolevstve S.Kh.S., n 9, 21 March 1922.

22. Zemgor Archive, Arkhiv n¹43, Bolgariia 1921-1930, Report n² 25, 23 September 1922. 
were sufficient to maintain life, but scarcely more. Charitable organisations therefore stepped in to supplement the French supplies and improve the conditions of life.

The most important such organisation was possibly the American Red Cross, which provided tents and medical aid, as well as additional rations for those most in need. ${ }^{23}$ Three Russian charities also played an important role. These were the Russian Red Cross, the Vserossiiskii Zemskii Soiuz, and the Vserossiiskii Soiuz Gorodov. Despite the similarity of their titles, the latter two were in fact entirely distinct from Zemgor. Indeed, as the director of the VZS, A.S. Khripunov, pointed out to Wrangel's mother, Mariia, in 1927, not only was the VZS independent of Zemgor, but politically its stance was entirely different too. ${ }^{24}$ Nevertheless, it was through the VZS and VSG that Zemgor operated in providing aid to the Russian Army.

Because so many organisations were involved in the provision of aid, it did not take people long to come to the conclusion that it would be more efficient if the various groups involved in the aid business coordinated their work under some form of central control. As a first step in the direction, the VSG, VZS and Russian Red Cross formed the previously mentioned Central United Committee (TsOK) to coordinate their activities. Zemgor, however, soon came to overshadow the TsOK.

On the ground in Turkey Zemgor had little if any direct contact with the army. Zemgor got some $60 \%$ of its income from the Committee of Ambassadors and $40 \%$ from its own resources. It then passed on its money to organisations like VSG and VZS, who did the practical work of providing aid. ${ }^{25}$ The army's actual experience of charitable organisations was, therefore, with these groups not with Zemgor itself.

The experience appears to have been a positive one, appreciated by both sides. ${ }^{26}$ At Gallipoli, for instance, where part of the army was interned, the VZS opened a shop selling necessities at a low price, thus enabling the often starving refugees to supplement their meagre rations. It also helped to set up various workshops, which provided many of the material needs of the troops. These included a shoe workshop at Gallipoli which repaired some 5,000 pairs of shoes and boots, and made about 1,600 new ones before closing in August 1921. Another workshop made around 1,000 pieces of furniture and other items to furnish the bare accommodation in which the Russians lived. ${ }^{27}$ The Russian social organisations also spent money

23. The activities of the American Red Cross are described in J. A. Hutchins, "The Wrangel Refugees: A Study of General Baron Peter N. Wrangel's Defeated White Russian Forces, both Military and Civilian, in Exile" (MA thesis, Louisville, KY, University of Louisville, 1972): 46-64. This thesis is based on the archives of the ARC.

24. HIA, M. D. Wrangel Archive, Box 26, File 5, Letter, Khripunov to M. D. Wrangel, 16 November 1927.

25. Zemgor Archive, Arkhiv n 138, Letter, V. Rudnev to Viktor Diodorovich [Brianskii], $\mathrm{n}^{\circ} 7602,5$ June 1923.

26. For details of the aid provided by these organisations to the Russians at Gallipoli, see "Deiatel'nost' obshchestvennykh organisatsii," in Russkie $v$ Gallipoli: sbornik statei (Berlin, 1923): 343-354; and Ocherk deiatel'nosti Vserossiiskogo Zemskogo Soiuza za granitsei, op. cit.

27. Russkie v Gallipoli: sbornik statei (Berlin, 1923): 346. 
providing musical instruments, linen, clothing, soap, paper, cooking materials, hairdressing equipment, tobacco, and medicine, and gave funds for building churches, officers' messes, and bathrooms in the various camps of the army. They provided meals for children (several hundred of whom had accompanied the army into exile) and the sick, and for those recuperating from illness. ${ }^{28}$ By October 1921, they had provided 184,000 such meals at Gallipoli alone. ${ }^{29}$ The VSG also subsidised educational courses for soldiers in the camps, as well as libraries, sports leagues, choirs, theatres, and the printing of newspapers. ${ }^{30}$ In all these ways, Russian social organisations, whose activities were in part indirectly funded by Zemgor, played an important role in alleviating the undoubtedly harsh conditions of life of those army members who remained in the camps in Turkey in 1921.

At first, some in army confused VSG and VZS with Zemgor, which led to a certain suspicion of their activities. But after the arrival in April 1921 of new representatives of those organisations who "caught the pulse of the army", this ceased. On visiting Gallipoli, the head of the VZS, A. S. Khripunov, commented that "he had never anywhere observed such a merging of obshchestvennost' and the army as at Gallipoli". ${ }^{31}$ The official history of the Russian Army at Gallipoli concluded that, "There was not a single corner of the Russian Army at Gallipoli which did not feel the help of the union [the VZS]", 32

As well as working through organisations like the VZS, Zemgor also occasionally acted behind the scenes to protect the interests of members of the Russian Army. This became clear in March 1921 when the French authorities announced that they would no longer provide rations to the Russian Army, whose members were to be given three options: return to Russia; go to Brazil, where the state of Sao Paolo had offered work to some 10,000 Russians; or find work where they were. ${ }^{33}$ The last was an impractical option given the lack of work for foreigners in Constantinople, and Brazil was immensely unpopular since the Russians had only been offered employment as low paid plantation labourers. In practice, the choice was one of repatriation (which would have meant possible death for many because of their anti-Soviet pasts) or starvation.

At this point, Zemgor rallied to the army's defence. The Zemgor Committee in Paris wrote to Briand requesting that the provision of rations to the army be continued, and subsequently also requested that the rations be increased. ${ }^{34}$ In the end the French backed down and continued feeding the Russian Army, largely because the Army itself refused to disband, and because they had little choice but to

28. Ibid.: 349-350.

29. Ibid.: 351 .

30. Ibid.: 352 .

31. Ibid.: 354 .

32. Ibid.

33. COC, C $20 \mathrm{~N}$ 1154, Telegram, Briand to Charpy, 11 March 1921.

34. Zemgor Archive, Box "Diplomaty - Sovet Poslov", Letter to Briand, 25 March 1921. Also, Vserossiiskii Zemskii Soiuz, Biulleten' Vremennogo Glavnogo Komiteta, 2 (July 1921): 95-96. 
feed the troops if they were to avoid army members taking drastic, even violent action to ensure their survival. Zemgor's intervention was probably not crucial in this regard, but it did at least reveal that the organisation was not perhaps as hostile to the army as some of its members imagined.

Zemgor also spoke out against the repatriation of Russians. ${ }^{35}$ This also put it on the same side as the army leadership, which resisted efforts by the French and later Nansen to repatriate thousand of Cossack soldiers from the army. However, Zemgor's approach to the matter was somewhat different from that of the army leadership, and this caused further conflict between the two. Thus, when protesting against French plans to repatriate members of the army or send them to Brazil, Zemgor noted that the former option would put the lives of many at risk, while the latter would condemn them to exploitation and possibly a "hungry death". But, Zemgor also stated its belief that the army should be dispersed. ${ }^{36}$ Wrangel was by this stage willing to see the army move out of Turkey, but still hoped to do so in a manner which kept it together. As such, he and Zemgor were still working in opposite directions.

Disputes over repatriation continued into 1923, when Nansen signed an agreement with the Soviet government in which the latter agreed to permit refugees to return and gave them guarantees for their safety if they did so. Nansen's willingness to trust these promises reflected the growing international acceptance of communist rule in Russia. One of Nansen's colleagues, T. F. Johnson, noted that Nansen believed that the return of refugees to Russia constituted "by far the best solution" to the refugee problem, and the agreement reflected his stance. ${ }^{37}$ Nansen's behaviour caused outrage in army circles, which did not want to weaken the forces of the anti-Soviet opposition in exile by having refugees return home. In May 1923, Wrangel's political advisor S.N. Il'in issued a circular complaining that the members of Zemgor had introduced a resolution supporting Nansen's efforts to negotiate a repatriation deal with the Soviets. Zemgor had no right to speak on behalf of Russian refugees, claimed Il'in. Indeed, Zemgor was an organisation alien to their interests, whereas those organisations who did speak for the mass of émigrés took an entirely different view of repatriation and the activities of Nansen. Those thinking of trusting Nansen's promises should be warned, Il'in concluded. ${ }^{38}$

Two members of the Zemgor Committee, N. Astrov and S. Panin denied Il'in's claims. They stated that the resolution in question had not been passed, largely because it was no longer necessary, Nansen having already signed an agreement with the Soviets. Zemgor did not believe that repatriation could solve the refugee

35. See for instance, Memorandum to the International Committee of the Red Cross and the Council of the League of Nations from Representatives of the Russian Red Cross and the Zemsko-Gorodskii Committee in Geneva, 15 June 1921.

36. Zemgor Archive, Box "Diplomaty - Sovet Poslov", Letter to Briand, 25 March 1921, and untitled, undated Report, probably March 1921.

37. T. F. Johnson, International Tramps: From Chaos to World Peace (London: Hutchinson, 1938): 279.

38. HIA, WA, Box 149, File 39: 535-538, Circular, S. N. Il`in, n k/2075-2084, 16 May 1923. 
problem, they said, but Zemgor did recognise that some refugees wished to return to the Soviet Union and were in some cases already doing so. In the circumstances, they concluded, it was better that they return with some care provided to them by the High Commissioner than without it. ${ }^{39}$ The army leadership, perhaps fearing the loss of its men, objected that Soviet promises could not be trusted. Again, one can see here how the issue of repatriation touched on the future of the army and so was political in nature as much as humanitarian.

Concluding this section, one can see that in practice Zemgor did help to alleviate the harsh conditions experienced by Russian soldiers after their withdrawal from the Crimea. Zemgor did not, though, get the credit due to it for this because it worked indirectly through third parties, primarily the VZS and VSG, and also because it focused its support on aid to individuals, while opposing the maintenance of the army qua army. Zemgor made not have realised it, but this opposition was an act of politics, and was interpreted as such. It caused a bitter reaction which complicated the provision of aid more than was strictly necessary.

\section{The Provision of Aid in the Balkans and Czechoslovakia}

In a rare example of cooperation (albeit indirect), Zemgor, the Ambassadors, and the Army High Command managed in late 1921 to find new homes for the troops of the Army in Bulgaria and Yugoslavia, both of whose governments viewed the White cause favourably. Wrangel's chief of staff General P. N. Shatilov reached an agreement with the Yugoslav and Bulgarian governments in 1921, as a result of which the bulk of the army moved to those countries as an organised mass in the last few months of that year.40 This represented a victory of sorts for the army command, as the units of the army remained to some extent intact. This merely put off the day of the army's final disintegration, but it did allow it to maintain some sort of military structure and to evolve gradually into a new body, ROVS. Leaders of the army and their supporters claimed that by keeping the army together they were able to provide much better humanitarian assistance to their soldiers than would have been possible if the plans of the French and Zemgor to disperse the army rapidly had been carried out.

As a postscript to this part of the story, however, it should be noted that Zemgor did help to some small degree in the transfer of Wrangel's troops to Yugoslavia and Bulgaria. Under the terms of the treaties Shatilov negotiated with the Yugoslavs, the Russians had to provide the Yugoslav government with a sum of $\$ 400,000$. As Wrangel did not have such money himself, he had to ask the Ambassadors for it, and Ambassador Bakhmeteff agreed to supply the money. Bakhmeteff then sent

39. HIA, WA, Box 149, File 39: 539-540, Letter, N. Astrov and S. Panin to Iu. I. Lodyzhenskii, $\mathrm{n}^{\circ} 833,4$ May 1923.

40. For details of these negotiations and agreements see Robinson, The White Russian Army...: 45-46. 
Prince L'vov and V.F. Zeeler from Zemgor to Yugoslavia to complete the arrangements, and reduce the amount demanded from 400 dinars per person per month for two years to only 300 dinars per person per month for only 10 months. ${ }^{41}$ This was a very rare case of everybody pulling together in the same direction, and it brought positive results, enabling the transfer of elements of the Russian Army to Yugoslavia to take place smoothly and without undue complications.

Once the army had taken up residence in Yugoslavia and Bulgaria, it survived off a number of sources of revenue. One of these was the money provided by the Ambassadors. Another was the wages soldiers themselves earned by leaving the formal structure of the army to find work, or in the case of Yugoslavia through organised work projects in which whole units of the army were kept together in the border guards, and road and rail building. In addition, the army raised some 37 million dinars from the sale of the assets of the Petrograd Credit Institution. ${ }^{42}$ These were deposits for loans placed in the Institute prior to the Revolution, which had fallen into the army's hands after the Institute moved them to the south of Russia for safe keeping during the Civil War. The army used the funds to provide personal loans, training and education, medical care, and sanitation. ${ }^{43}$

Even with these resources, the conditions of life for many, if not most, members of the army remained very difficult. For this reason, aid provided by the VSG, VZS, and Red Cross continued to play an important role in improving the quality of their lives. A large portion of the funds for such aid continued to come from Zemgor.

Politically, the VZS and VSG remained close to Wrangel. When he attempted to re-establish political leadership over the Russian emigration by creating in 1921 a Russian Council, led by him but with representatives from Russian social organisations, they agreed to participate in it. In this way, they highlighted again the political nature of aid organisations. In summer 1922, however, the VSG left the Council after elections to it produced a majority of monarchist delegates. ${ }^{44}$ This decision, paralleled by the defection of some other groups, spelt the death of the Council, which Wrangel disbanded soon afterwards. Further efforts to unite the emigration politically continued for years, but from this point on the army abandoned the attempt to take the lead itself.

Interestingly, despite cutting the ground from under Wrangel's Russian Council, the VSG's political position was very similar to that of the Russian general and his staff. For in complaining that monarchist groups had taken over the Council, it was echoing a complaint made by Wrangel himself, as the general was at this time embroiled in a bitter conflict with monarchist groups. ${ }^{45}$ Thus, while the army's

41. Vserossiiskii Zemskii Soiuz, Biulleten’ Vremennogo Glavnogo Komiteta, 2 (July 1921): 95-96.

42. Davatz, Fünf Sturmjahre mit General Wrangel:112-113.

43. Ibid.: 113 .

44. Zemgor Archive, Arkhiv n 138, Iugoslaviia 1922-1923, Informatsiia Predstavitel'stva Vserossiiskogo Soiuza Gorodov v Korolevstva S.Kh.S, n 24, 26 July 1922.

45. Robinson, The White Russian Army.... 62-63. 
relations with Zemgor remained poor, its relations with the organisations through which Zemgor channelled its money to provide aid on the ground in the Balkans remained good.

In Bulgaria the VZS, through its representative V. S. Resnichenko, worked very closely with the army, to which it continued to provide aid, particularly once its members began to disperse in search of employment or further education. One of the main concentrations of Russian soldiers was at the Pernik mines in Bulgaria, where several thousand worked. In October 1922, VZS reported that it was organising a tea-room and library at Pernik. ${ }^{46}$ Some years later, Zemgor itself was in contact with Russian officers there. In 1925, the Circle of Russian National Youth at Pernik wrote to Zemgor asking for books and magazines to support its work in "preserving among its members a love of the Motherland, the national religion, national history, literature, and the great Russian language". The Circle claimed 140 members in Pernik and 60 elsewhere. In January 1926, Zemgor despatched 20 books to Pernik in response. ${ }^{47}$

This exchange was of some wider interest in that the Circle of Russian National Youth was the organisation which later evolved into the Natsional'nyi Trudovoi Soiuz (NTS), one of the more active political bodies in the Russian emigration in the 1940s, especially in the years of the Second World War. It appears, therefore, that though Zemgor was unwilling to support the army, it was not opposed to supporting nationalist organisations per se. In a similar way, the VSG helped to organise scout and sokol organisations in Yugoslavia in the early 1920s, ${ }^{48}$ thus helping to bring up émigré youth in a nationalist spirit.

More generally, in the early 1920s the VSG and VZS provided aid to army members in a wide variety of ways. Accounts from early 1922, for instance, record expenditures on workshops, educational courses, hostels, subsidised restaurants, foreign language courses, and so on. ${ }^{49}$ Not all of this expenditure was directed towards army members, but as they constituted much of the emigration in the Balkans, a substantial portion of it must have reached them.

One of the main areas supported by Zemgor through VZS and VSG was education. Many members of the Russian Army had failed even to complete their High School education when in Russia, having left school to join the army either in World War One or during the Civil War. Lacking any sort of High School Diploma, they now found it difficult to find any form of white collar employment, while it

46. Zemgor Archive, Arkhiv n 143, Bolgariia 1921-1930, Report n² 28, 14 October 1922.

47. Zemgor Archive, Arkhiv n 143, Bolgariia 1921-1930, Letter from the Informatsionnyi otdel po Kruzhke Russkoi Natsional'noi Molodezhi, n 11, Pernik, 24 September 1925. Also, Letter, $n^{\circ} 21$ to V. Rudnev, 23 November 1925; and Letter, V. Rudnev to the Circle of Russian National Youth, 13 January 1926.

48. Zemgor Archive, Arkhiv n 138, Iugoslaviia 1922-1923, Informatsiia Predstavitel'stva Vserossiiskogo Soiuza Gorodov v Korolevstve S.Kh.S., n 14, 25 April 1922.

49. For instance, Zemgor Archive, Arkhiv n 136, Iugoslaviia 1922-1925, Smeta raskhodov Vserossiiskogo Zemskogo Soiuza na okazanie pomoshchi rossiiskim grazhdanam, nakhodiashchim v Serbii na period fevral’1922 goda. 
was also impossible for them to gain such diplomas since they were now well beyond normal school age, and Yugoslav and Bulgarian schools were unwilling to educate them.

To deal with this problem, the VSG in Yugoslavia set up a course to enable army members to receive a school leaving certificate. Lacking sufficient resources to fund this course itself, the VSG appealed to Zemgor for aid, noting "our moral obligation towards the military youth, who have shed their blood for Russia" ${ }^{50}$ In response, Zemgor agreed to assign some 7,000 dinars a month to the courses, which began in Panchevo in September 1923.51 In this way, it helped several dozen army members build better lives for themselves in exile.

Politics, though, intruded even into the world of schooling. The politicallyminded understood that what young exiles learnt could help determine their subsequent attitudes. For this reason, the army leadership was keen to include a strong national element in Russian education overseas, as well as some military training through the Cadet Corps in Yugoslavia, and physical education to build strong fighters for the future army. This brought the army into conflict with more liberal elements of the emigration who wanted to focus more on providing an education which would help young émigrés find useful employment or further education. Thus, in 1927 a librarian at the Zemgor-controlled Russian school in Varna, Bulgaria, complained that it was very difficult to introduce organised sports into the curriculum because Zemgor officials had a great fear of even a hint of something that reminded them of the military. ${ }^{52}$

Although receiving a school leaving certificate mattered to some army members, more were concerned with entering higher education to receive a university degree. The prime destination in this regard was Czechoslovakia. In 1921, the Czech government agreed to let a first batch of 100 soldiers from Gallipoli enter the country to study at university. Once the army moved to Yugoslavia and Bulgaria, many others in the army began to leave its ranks and head to Czechoslovakia to join their former colleagues in their studies. This was especially true of those in Bulgaria. In 1922 the Bulgarian government of Alexander Stamboulisky turned on the Russian Army, arrested many of its commanders, and accused its members of plotting a coup. Fearing further persecution, many Russians decided to flee westwards.

In Bulgaria, the VZS provided aid to army members to travel to Czechoslovakia to go to university..$^{53}$ For the most part, though, would-be students travelled at their

50. Zemgor Archive, Arkhiv n 138, Iugoslaviia 1922-1923, Letter, Special Representative of VSG to Zemsko-Gorodskoi Komitet, n⿳ 558, 5 April 1923; and Arkhiv n 139, Iugoslaviia 1923-1927, Informatsiia Predstavitel'stva V.S.G. v Korolevstve S.Kh.S, n 58, 3 October 1923.

51. Zemgor Archive, Arkhiv n 139, Iugoslaviia 1923-1927, Letter, Rudnev to Brianskii, $n^{\circ}$ 9313, 12 November 1923.

52. Gosudarstvennyi Arkhiv Rossiiskoi Federatsii, f.5826, op. 1, d. 193, 1.44, Letter, A. Kurbatov to General Gulevich, 1 September 1927).

53. Zemgor Archive, Arkhiv n 143, Bolgariia 1921-1930, Report n 32, 11 November 1922. 
own expense, and in general entered Czechoslovakia illegally. ${ }^{4}$ Once there, lacking any means of support or any legal status, they relied for support primarily on the Prague Committee of Zemgor. One Gallipoli veteran, Colonel V.V.Almendinger, who eventually received a $\mathrm{PhD}$ in agricultural sciences, described how, after entering Czechoslovakia illegally, he arrived in Prague with just 50 crowns in his pocket. To regularise his position, he visited the offices of Zemgor bearing a letter of recommendation. Zemgor then gave him some money and a letter to the relevant Czech ministry to legalise his status in the country. After this, he received the papers which allowed him to stay, and began studies at the Agricultural Institute of Brno. ${ }^{55}$

Almendinger's experience was a common one. In the early 1920s, Prague Zemgor helped to bring 438 students from the Russian Army to Czechoslovakia through legal channels. It also worked to legalise the situation of several thousand others who had entered the country illegally. It did this by registering them with the Russian Department of the Czech Ministry of Foreign Affairs, which trusted Zemgor to act as its agent in these matters. ${ }^{56}$ Zemgor registered 1,753 people in this way in $1921 ; 1,974$ in $1922 ; 1,317$ in 1923 ; and 527 in $1924 .{ }^{57}$

Despite the aid which Prague Zemgor provided to army members in this way, the army continued to regard it as a hostile organisation. Again, this was a case of the military and social organisations working together happily at the lower end while assuming positions of outright hostility at the higher levels.

For example, Wrangel's representative in Czechoslovakia, General Leontev, noted that in June 1921 Prague Zemgor opened a registration department to give out residence permits in Czechoslavakia. This, he said, had caused great worry that the documents previously given out by diplomatic and consular representatives would no longer be valid: "Diplomatic institutions, consulates and military agencies, like other representatives of old Russia are now a thorn in the flesh of left-wing parties", Leontev wrote, "and all their efforts are now directed towards weakening their influence and significance and to discrediting them. It would be difficult, if not impossible, to do this under the flag of the socialist-revolutionaries ... and so they have constructed a very cunning plan, to exploit the majority held by members of the Prague socialist-revolutionary staff within Zemstvo and Town institutions to form a Prague branch of Zemgor, and under its flag continue their former work" 58

The image of Prague Zemgor as an undercover branch of the SocialistRevolutionary Party had at least some basis in reality. Of 63 members of the Prague

54. For a description of how this was done, see V.V. Almendinger, Gallipoliiskoe zemliachestvo v Brno: pamiatnaia zapiska o zhizni gallipoliitsev v Brno (Huntington Park, California, 1968): 11-14. Copy held at the Marriott Library, University of Utah, Salt Lake City.

55. Almendinger, Gallipoliiskoe zemliachestvo...: 14-17.

56. Ocherk deiatel'nosti Ob"edineniia Rossiiskikh Zemskikh i Gorodskikh Deiatelei V Chekhoslovatskoi Respublike "Zemgor"(Prague, 1925): 26-27.

57. Ibid.: 30 .

58. HIA, E. K. Miller Archive, Box 15, File 25, Letter, Leontev to Miller, n 90, 15 June 1921. 
Zemgor Committee in 1925, there were no fewer than 29 SRs. Of the remainder, only 10 were members of no political party, there were two Cadets (who could be described as centrists in political terms), and the remainder were all members of other left-wing groups: there were three Narodnye-Sotsialisty, one SocialDemocrat, three members of Krestianskaia Rossiia, and 15 members of the Soiuz Vozrozhdeniia Kazachestva. ${ }^{59}$

This membership gave the organisation a decidedly left-wing political complexion. Given that a large proportion of the Russians in Czechoslovakia were former soldiers, either Cossacks or officers of the Russian Army, Zemgor's leadership certainly had a different orientation from those it was supposedly representing, and to whom it was giving aid. It is noticeable that the only member of Prague Zemgor who described himself as an officer of the army general staff was Col F. E. Makhin, and he was a Socialist-Revolutionary.

The fact that the Cossacks within Prague Zemgor were from the Soiuz Vozrozhdeniia Kazachestva is also revealing. This organisation was created in December 1920 by radical political activists among the Don, Kuban, and Terek Cossacks. It blamed the White generals for the Cossacks' defeat in the Civil War, and while calling for continued struggle against the Bolsheviks, demanded statehood for the Cossack peripheries of Russia, and insisted that the Cossacks reject the leadership of the army High Command. ${ }^{60}$

There were strong suspicions that groups such as this exploited their dominant position within Zemgor for party political purposes. Thus in June 1924, Wrangel's representative in Poland, General P. S. Makhrov, noted that 200 Russians soldiers, including a group of Ural Cossacks, who had previously been interned in Poland, had left to work and study in Czechoslovakia. There, Makhrov claimed, they found that despite Zemgor's claims to the contrary it had a definite political character. Zemgor formed a Cossack group to organise a social congress to unite Cossacks in Czechoslovakia, which the Ural Cossacks attended. However, this congress turned out to have a political agenda, and at it General Sidorin made a speech hostile to the Commander-in-Chief. The Uraltsy left the Congress in protest. This, Makhrov stated, put them in a delicate situation, as they need to enter some sort of organisation to legalise their position in the counry. ${ }^{61}$

Prague Zemgor responded to such claims in a robust fashion. According to a bulletin issued by it:

From the moment of the Union's creation certain circles of the Russian emigration in Prague have struggled in earnest against Zemgor, with the aim of taking responsibility for the care of Russian refugees out of the hands of Zemgor. Efforts have been made to discredit its activity, both in front of the government of the Czechoslovak Republic and in front of the refugee masses and refugee aid

59. Ocherk deiatel' nosti Ob"edineniia Rossiiskikh Zemskikh i Gorodskikh Deatelei...: 12-13.

60. Grigorii Rakovskii, Konets Belykh (Prague: Izdatel'stvo "Volia Rossii”, 1921): 229-233.

61. HIA, P. A. Kussonskii Collection, Box 10, File 40, Letter, Makhrov to Miller, n 181, 16 June 1924. 
organisations. Zemgor has been accused of partiinost' in the one-sided, tendentious character of its activity, rumours have been spread about abuses committed by its leaders, and they have been reproached for complete incompetence. At the same time, efforts have been made to demonstrate that the mass of Russian refugees does not sympathise with Zemgor by means of resolutions brought forward by several Russian organisations in Prague. ${ }^{62}$

Both the left and the right had engaged in these attacks, claimed Zemgor. "Monarchist circles particularly hate Zemgor because it is an apolitical organisation, which has decisively rejected any efforts to create overseas an armed force for struggle against the Bolsheviks" (a revealing statement, for that rejection was a political act, and so contradicted Zemgor's claim to be apolitical). ${ }^{63}$ Zemgor listed the organisations opposing it, which it said had "an insignificant number of members, and no influence over broad émigré circles". Examples were: the National Committee (a centrist political organisation, closely aligned with Wrangel), the Torgovo-Promyshlennyi Committee, the Society of Officers, the Damskii Kruzhok, and the Russian Red Cross committee for aid to children. ${ }^{64}$

Zemgor explained the campaign against it by attributing to its opponents exactly the same motives that they were assigning to it: "the desire of certain political circles to seize the business of aid to refugees in their hands, to make refugees dependent on them, and by means of this dependence enable themselves to use the émigré mass in pursuit of their political goals." 65

A balanced view would conclude that both sides in these disputes were halfright and half-wrong. Both Zemgor and the army claimed to be apolitical, while accusing the other of partiinost'. In practice, they were right to note the political nature of their opponents, while wrong to deny the political nature of their own activities. However much Prague Zemgor may have imagined itself an apolitical body, the profile of its membership made it impossible for others to accept it as such.

The perception that Prague Zemgor was a socialist front organisation undoubtedly put obstacles in its way. This can be seen in the curious episode of the aforementioned Colonel Makhin, who in March 1924 appeared in Belgrade on a mysterious mission from Prague Zemgor. His visit baffled the representative of the VSG in Belgrade, V. D. Brianskii, who wondered why Makhin had neither warned him of his arrival nor chosen to visit him. Brianskii felt that Makhin's mission had "a political character". He learnt from others that the colonel had told them that he had established contact with officials in the Yugoslav government and was visiting as a first step in a plan to extend Prague Zemgor's work into Yugoslavia. ${ }^{66}$ Prague

62. Ocherk deiatel'nosti Ob"edineniia Rossiiskikh Zemskikh i Gorodskikh Deatelei.... 34.

63. Ibid.: 35 .

64. Ibid.

65. Ibid.

66. Zemgor Archive, Arkhiv n 139, Iugoslaviia 1923-1927, Letter, V. D. Brianskii to Zemsko-Gorodskoi Komitet, n 357, 10 March 1924. 
Zemgor denied this, saying that it had no concrete plans to expand into that country, and that Makhin's task was merely to see if graduates of Prague Zemgor's tractor courses could find work in Yugoslavia. ${ }^{67}$

Whatever the truth, this was not the end of the matter. In August 1925, General Wrangel complained that Makhin was once again in Yugoslavia. He claimed that Makhin's aim was to penetrate the ranks of military refugees under the cover of Zemgor's charitable work in order to carry out propaganda on behalf of the Party of Socialist Revolutionaries. He therefore tasked his official representative in Yugoslavia, Colonel V. I. Bazarevich, to protest to the War Ministry in order to paralyse Makhin's activity. ${ }^{68}$ Bazarevich later reported that he had succeeded in persuading the Yugoslav Ministry of Foreign Affairs to cancel a circular it had issued giving support to Makhin. ${ }^{69}$ Nevertheless, Prague Zemgor did establish an office in Yugoslavia, which it ran until 1928, after which the office continued as a separate organisation under the control of Colonel Makhin.

Makhin's mission illustrates the political nature of aid. It is quite possible that Makhin had no political agenda, and his concerns were purely humanitarian. But simply by arriving in Belgrade, he trod on the toes of other aid organisations. In addition, whatever Prague Zemgor's actual motives, the plain fact that it was dominated by members of left-wing parties meant that others were always going to interpret its actions in a political light. Furthermore, the relative inability of Prague Zemgor to penetrate Yugoslavia reflected the different political situation in that country compared with Czechoslovakia. While the Czech government favoured left-leaning organisations like Zemgor, the more conservative Yugoslav government remained largely loyal to the Russian Army. Which organisations dominated the aid effort in which countries depended in large part on the political orientation of the countries in question.

\section{Conclusion}

It is clear from this history that it was impossible to isolate the business of humanitarian aid from the severe political divisions which beset the inter-war Russian emigration. It is tempting to imagine that some way could have been found to unite the efforts of all organisations to use the few resources available to the emigration in a more efficient manner. Looking at the conflicts between the Army High Command and social organisations in Constantinople, one study concluded that these had reduced the effectiveness of material help to the refugees. ${ }^{70}$ The struggles for power brought "significant harm" to the already hard position of

67. Zemgor Archive, Arkhiv n 139, Iugoslaviia 1923-1927, Letter to Brianskii, 25 March 1924.

68. HIA, WA, Box 146, File 31: 557, Letter, Wrangel to Kondzerovskii, 6 August 1925.

69. HIA, WA, Box 146, File 31: 560, Letter, Bazarevich to Kussonskii, 18 August 1925.

70. Ippolitov et al., "Rossiiskaia emigratsiia v Konstantinopole..." (art. cit. note 15): 84. 
refugees. ${ }^{71}$ This is possibly an exaggeration, since the resources available to the emigration were too limited for very much more to have been done than was actually done. Nevertheless, the conflicts which surrounded the aid question can not have helped the delivery of support to those most in need. Unity could only have made things better.

In practice, though, it is hard to see how this could have been achieved. Politics could not have been avoided. Zemgor's belief that it was apolitical does not hold up to close scrutiny, since the simple fact of accepting the role of prime aid coordinator was a political act, denying Wrangel's claims to leadership and the army's claim to priority in the distribution of resources. As soon as Zemgor accepted the role the Ambassadors offered it, it could not avoid conflict with the Army. On the other hand, to have accepted Wrangel's leadership would also have been a political statement. The history of the conflict between Zemgor and the Army proves that the provision of aid cannot be divorced from politics, and that those involved in it are as much political actors as they are social ones.

University of Hull, United Kingdom

Paul.Robinson@hull.ac.uk

71. Pivovar, Rossiiskaia emigratsiia v Turtsii. (op. cit. note 16): 25. 